\title{
Performance of cowpea (Vigna unguiculata (L.) Walp) under irrigation as influenced by weed management methods and intra row spacing
}

\author{
Na-Allah M. S. ${ }^{1 \star}$, Mukhtar A. A. ${ }^{2}$, Mahadi M. A. ${ }^{2}$, Tanimu M. U. ${ }^{1}$ and Muhammad A. ${ }^{1}$ \\ ${ }^{1}$ Department of Crop Science Kebbi State University of Science and Technology, Aliero, Nigeria. \\ ${ }^{2}$ Department of Agronomy Ahmadu Bello, University, Zaria, Nigeria. \\ ${ }^{*}$ Corresponding author. Email: mustaphanaallah@gmail.com
}

Copyright @ $2017 \mathrm{Na}$-Allah et al. This article remains permanently open access under the terms of the Creative Commons Attribution License 4.0, which permits unrestricted use, distribution, and reproduction in any medium, provided the original work is properly cited.

Received 22nd May, 2017; Accepted 1st August, 2017

\begin{abstract}
The study was conducted in the dry season of 2014/2015 at two locations: the experimental Farms of the Institute for Agricultural Research, Ahmadu Bello University Samaru, Zaria and Kadawa Kano, located in the Northern Guinea and Sudan Savanna Ecological Zones of Nigeria, to assess the effects of weed management methods and intra row spacing on performance of cowpea. The experiment was laid out in a split plot design with three replications. Treatments were five weed control methods involving the use of Pendimethalin at $1.0,1.5$ and $2.0 \mathrm{~kg}^{\mathrm{a} . \mathrm{i}}$. ha ${ }^{-1}$, two hoe weeding at 3 and 6 weeks after sowing (WAS) and a weedy check and four intra row spacing (20,25, 30 and $35 \mathrm{~cm})$. The herbicide treatments were assigned to the main plots while intra row spacings were assigned to the subplots. Results indicated that weed coverage score, weed density and weed dry weight were significantly decreased by the weed control methods compared to weedy check treatments. The application of Pendimethalin at the rate of $2.0 \mathrm{~kg}$ a.i $\mathrm{ha}^{-1}$ and two hoe weeding at 3 and 6 WAS resulted to significantly higher values for plant height, canopy spread and crop growth rate. Yield parameters including number pods per plant, seed weight and grain yield were also significantly increased in the herbicide treated plots and two hoe weeding compared to weedy check. In conclusion, the results obtained from this study indicated that two hoe weeding at 3 and 6 WAS and $20 \mathrm{~cm}$ intra row spacing effectively controlled weeds and produced the highest grain yield $\left(\mathrm{kg} \mathrm{ha}^{-1}\right)$ in Samaru, Zaria and Kadawa, Kano.
\end{abstract}

Key words: Cowpea grain yield, intra row spacing, treatments, weed control.

\section{INTRODUCTION}

Cowpea (Vignaunguiculata (L.) Walp) is a tropical herbaceous annual legume crop. It belongs to the family Fabaceae (formerly Leguminoseae) and sub family Papilinoideae of flowering plants. Kay (1979) cited Northeastern Nigeria as cowpea center of origin. Cowpea is the most important food legume in Semi-Arid Tropics covering Asia, Africa, Southern Europe and Central and South America (Singh, 2007). The major constraints to cowpea production are the presence of insect pests, diseases, plant parasitic weeds, drought and heat (Jackai et al., 1999). The cowpea plant is attacked by pests during every stage of its life cycle. Cowpea is infested by a number of weed species that compete with the crop right from germination to harvest, affecting the crop yield adversely (Yadav et al., 1998). Striga and Alectra species are the major parasitic weeds infesting cowpea and severe yield losses have been reported by Aggarwal and Ouedrago 1989. Weeds also deteriorate the quality of produce through the physical presence of their seeds and debris. This emphasizes the need to control weeds in order to obtain optimum crop yield.

Herbicides, if properly used are safe and effective in controlling weeds in cowpea. The choice of herbicide however, partly depends on the predominant weed species and the availability of the herbicide. If herbicide is used at planting one hoe weeding may be required at 4 to 5 weeks after sowing. Application of a tank mixture of paraquat and pendimethalin within two days of planting is 
recommended (Dugje et al., 2009). Paraquat controlled emerged grass and broad leaf weeds while Pendimethalin prevents weed seeds from germinating. According to Silva et al. (2003), the best post emergence weed control in cowpea was provided by phenoxapropethyl at the rate of $80 \mathrm{gha}^{-1}$ associated with glyphosate $\left(1800 \mathrm{gha}^{-1}\right)$ and it was effective against grasses. The conventional method of weeding such as hoeing, hand weeding and harrowing is expensive and labor is not available during peak workload (Khan et al., 2000). Therefore the use of herbicides in cowpea to control weeds appears to be useful (Dadari,2003; Silva et al., 2003). In general herbicides are effective only against few weed species which result in a serious infestation of other weeds. The phenomenon involved in crop yield increase as affected by different weed control methods has been well described by many researchers (Bukhtiar et al., 1992; Tomar et al., 2003; Patel et al., 2003). Tripath and Singh (2001) reported that the presence of weed in cowpea reduced yield by $82 \%$ whereas significant increase in pod yield was noted by controlling weeds up to 45 days of sowing. Parasuraman (2000) found that application of Pendimethalin (1.5 or $2.0 \mathrm{~L} / \mathrm{ha}$ ) or (fluchloralin 1.0 or $1.5 \mathrm{Lha}^{-1}$ ) at 3 days + hand weeding twice at 30 days after sowing (DAS) resulted in significant reduction in weed population, dry matter and an increase in crop yield in rain fed cowpea. In an experiment to evaluate weed management strategy for cowpea, Patel et al. (2003) found that pre emergence application of Pendimethalin at $0.75 \mathrm{~kg}$ a.i ha $\mathrm{h}^{-1}+$ hand weeding at 5 weeks after sowing gave a higher grain yield $\left(511 \mathrm{kgha}^{-1}\right)$ and net return (RS.4705 ha) compared to other treatments. Jabir et al. (2004) reported that Pendimethalin at $1.0 \mathrm{~kg}$ a.i ha ${ }^{-1}+$ hand weeding at 30 DAS gave the highest cowpea yield while weed density and weed dry biomass was lowest in this treatment. According to Akobundu (1984) chemical weed control combined with other cultural practices such as hoe weeding may be practical in reducing weed competition, crop loss and labour cost.

Despite the numerous importance of cowpea, its yield in farmers' field is relatively low. According to Okafor and Adegbite (1991) weed could constitute a major limiting factor to cowpea production in Nigeria. Also, Tijjani (2001) reported that weed could cause yield losses of cowpea ranging from 50 to $80 \%$. The conventional methods of weeding such as manual and mechanical methods are expensive, tedious and labour intensive. Thus, in order to enhance cowpea productivity, efficient, economical and easier weed control method such as the use of herbicide is desirable. Also, intra row spacing has been reported to determine plant density which is a good measure of weed management and also classified as cultural control method through canopy management (Akobundu 1987). Ross and Lembi (1985) stated that when crops are maintained in dense stands, they are vigorous enough by themselves to keep weeds in check.
This study was therefore conducted to determine the effect of weed control methods and intra row spacing on performance of cowpea.

\section{MATERIALS AND METHODS}

Field trials were conducted during 2014/2015 dry season at the research farm of the Institute for Agricultural Research Samaru, Zaria located on latitude $11^{0} 11^{1} \mathrm{~N}$ and longitude $07^{0} 38^{1} \mathrm{E}, 686 \mathrm{~m}$ above sea level in the Northern Guinea Savanna Ecological Zone of Nigeria and at the Irrigation Research Station of the Institute for Agricultural Research, Kadawa located on latitude $11^{\circ}$ $39^{\prime} \mathrm{N}$ and longitude $080^{\circ} 20^{\prime} \mathrm{E}, 500 \mathrm{~m}$ above sea level in the Sudan Savanna ecological zone of Nigeria.

The experiment was laid out in a split plot design with three replications. Treatments were five weed control methods involving the use of Pendimethalin at 1.0, 1.5 and $2.0 \mathrm{~kg}$ a.i ha ${ }^{-1}$, two hoe weeding at 3 and 6 weeks after sowing and a weedy check and four intra row spacing $(20,25,30$ and $35 \mathrm{~cm})$. The experiment was laid out in a split plot design with three replications. The herbicide treatments were assigned to the main plots while intra row spacing was assigned to the subplots. Each subplot was made up of six ridges, $75 \mathrm{~cm}$ apart giving a gross plot area of $12 \mathrm{~m}^{2}$. The net plot area consisted of four middle ridges giving an area of $9 \mathrm{~m}^{2}$. Water channels were constructed for effective supply of water to each furrow during irrigation. The seeds were treated with Apron star at the rate of $10 \mathrm{~g}$ of the chemical per $4.0 \mathrm{~kg}$ of seed before sowing, in order to protect the seeds from soil borne diseases and pests. The seeds were sown first on the 19th of February 2015 in Samaru and on the 26th of February 2015 in Kadawa. The intra row spacing was as per treatment. Three seeds were sown per hole at $1.5 \mathrm{~cm}$ depth and later thinned to two seeds per stand. The herbicide Pendimethalin was applied immediately after sowing as pre emergence treatment, using a CP3 knapsack sprayer fitted with a green deflector nozzle calibrated to deliver 220 liter ha-1 spray volume at a pressure of $1.5 \mathrm{kgcm}^{2}$. Spraying was done in the morning when the weather was calm to avoid wind drift. Cowpea plant was sprayed at vegetative, flowering and podding stages with appropriate mixture of cypermerthrin plus dimethoate at the rate of $1.0 \mathrm{Lha}^{-1}$ to control pest. Harvesting was done manually by hand picking at intervals, when the pods in each plot turned brown and dried. The harvested pods were spread on the ground for six days to allow the pods to dry well before threshing. This was followed by winnowing to separate the seeds from the chaff.

The data were collected on weed cover, weed dry weight, plant height, canopy spread, number of pod per plant, seed weight and grain yield. The weed species in the experimental site were collected randomly from a 1 $\mathrm{m}^{2}$ quadrat within the plots and were identified and their 
Table 1. Common weed species and their level of infestation at the experimental sites in Samaru and Kadawa during 2014/2015 dry season.

\begin{tabular}{|c|c|c|}
\hline \multirow{2}{*}{ Weed species } & \multicolumn{2}{|c|}{ Level of infestation } \\
\hline & Samaru & Kadawa \\
\hline \multicolumn{3}{|l|}{ Grasses } \\
\hline Cynodon dactylon (L.) Pers & $\star \star \star *$ & ** \\
\hline Brachiaria deflexa S. & ** & ** \\
\hline Chloris pilosa Shumach & ** & ** \\
\hline Dactyloctenium aegyptium Linn & * & ** \\
\hline Digitaria horizontalis. Willd & * & ** \\
\hline Eleusine indica Gaertn & * & * \\
\hline Eleusine indica & ** & * \\
\hline Pennisetum pedicellatum Trin & ** & * \\
\hline \multicolumn{3}{|l|}{ Broad leaved } \\
\hline Euphorbia heterophylla Linn & $* * *$ & ** \\
\hline Euphorbia hirta (L) & - & * \\
\hline Amaranthus spinousus( $(I)$. & * & * \\
\hline Leucas martinicensis (Jacq). Ait.F & * & * \\
\hline Mitracarpus villosus (Sw).Dc & ** & * \\
\hline Physalis angulata Linn & - & * \\
\hline Commelina benghalensis $\mathrm{L}$. & * & * \\
\hline \multicolumn{3}{|l|}{ Sedges } \\
\hline Cyperus esculentus(L.) & * & * \\
\hline Cyperus rotundus Linn & * & $\star \star \star *$ \\
\hline
\end{tabular}

${ }^{* * *}$ High infestation (60-90\%), ${ }^{* *}$ Moderate infestation (40-50\%), *Low infestation (1-39\%).

intensity of occurrence was recorded. Data collected was subjected to analysis variance using SAS and the means were separated using Duncan multiple range test (Duncan, 1995).

\section{RESULTS}

The soil in Samaru was silt loam and sandy loam in Kadawa with medium pH 5.66 to 6.85 , low nitrogen, and phosphorus and potassium values. Metrological data of both locations are presented in Appendix Table 1. The records of temperature, sunshine hours and relative humidity were collected from the meteorological unit of the Institute for Agricultural Research Samaru and Irrigation Research Station at Kadawa during the experimental period (Appendix Tables 2a and b).

At Samaru, the common dominant weed species were grasses such as Cynadondactylon, Brachiaria deflexa, Digitaria horizontalis, Dactyloctenium aegyptium. This was followed by broad leaved weeds such as Euphorbia heterophylla, Mitracarpusvillosus, Commelina benghalensis and the least were sedges such as Cyperus rotundus and Cyperus esculentus. At kadawa, the common dominant weed species were also grasses such as Cynadon dactylon, Digitaria horizontalis, Chloris pilosa. This was followed by broadleaved such as Euphorbia heterophylla, Mitracarpus villosus, amaranthus sipinosus. The least were sedges such as Cyperus rotundus and Cyperus esculentus (Table 1).

\section{Weed coverage score and weed dry weight}

At 9 WAS, the highest weed coverage score was recorded in weedy check with mean value of 6.33. The least weed coverage was recorded in hoe weeded plots with mean value of 3.67 (Table 2). There was no significant effect on weed cover score in Samara, Kadawa and mean data for varying the intra row spacing from 20 to $35 \mathrm{~cm}$ throughout the sampling period. The effect of weed control and intra row spacing on weed dry weight is shown on Table 2. The weedy check plots recorded the highest weed dry weight at 9WAS in both locations. The lowest weed dry weight was recorded in the two hoe weeded treatment (Table 2). A significant difference was observed among the various intra row spacing at 9 WAS in Samaru with the $20 \mathrm{~cm}$ intra row spacing recording the least dry weight than 25,30 and 35 $\mathrm{cm}$.

\section{Cowpea height and canopy spread}

Cowpea height was significantly influenced by different weed control treatments (Table 3). Two hoe weeded plots produced the tallest plant followed by Pendimethalin at $2.0,1.5,1.0 \mathrm{~kg}$ a.i ha-1 while the shortest was observed in the weedy check at 9 WAS in Samaru. In kadawa and mean data, two hoe weeded plots and Pendimethalin at $2.0 \mathrm{~kg}$ a. i ha ${ }^{-1}$ produced the tallest plant while the shortest was observed in the weedy check (Table 3 ). Varying the intra row spacing from 20 to $35 \mathrm{~cm}$ significant difference at 9 WAS in Samaru where the $35 \mathrm{~cm}$ had the taller plants than the other spacing. There was no significant effect on intra row spacing at Kadawa throughout the sampling period. Canopy spread showed significant difference among the treatments. Hoe weeded plot had significantly wider canopy spread than other treatments. There was also significant difference on cowpea canopy spread in Pendimethalin at all rates but they differed from weedy check plots in both locations (Table 3). There was no significant difference on intra row spacing with respect to canopy spread at 9 WAS in both locations.

\section{Number of pods per plant and 100 seed weight}

In both locations the highest number of pod per plant was from the hoe weeded plot which was significantly higher 
Table 2.Effect of weed control methods and intra row spacing on weed cover score and weed dry weight of cowpea at 9 WAS in Samaru and Kadawa.

\begin{tabular}{|c|c|c|c|c|c|c|}
\hline \multirow{2}{*}{ Parameters } & \multicolumn{4}{|c|}{ Weed cover score $\left(\mathrm{m}^{2}\right)$} & \multicolumn{2}{|c|}{ Weed dry weight $\left(\mathrm{g} / \mathrm{m}^{2}\right)$} \\
\hline & Samaru & Kadawa & Mean & Samaru & Kadawa & Mean \\
\hline \multicolumn{7}{|l|}{ Weed control (w) } \\
\hline \multicolumn{7}{|l|}{ Pendimethalin (kg a.i ha-1) } \\
\hline 1.0 & $5.25^{b}$ & $7.42^{\mathrm{a}}$ & $6.33^{\mathrm{b}}$ & $87.08^{\mathrm{b}}$ & $57.92^{b}$ & $145.00^{b}$ \\
\hline 1.5 & $4.00^{c}$ & $7.50^{\mathrm{a}}$ & $5.75^{\mathrm{c}}$ & $84.08 b$ & $52.29^{b}$ & $134.37^{b}$ \\
\hline 2.0 & $3.42^{\mathrm{d}}$ & $7.50^{\mathrm{a}}$ & $5.87^{\mathrm{c}}$ & $77.51 b^{c}$ & $38.27^{b}$ & $115.78^{c}$ \\
\hline Two hoe weeding (3\& 6WAS) & $3.67^{d}$ & $5.25^{b}$ & $4.46^{d}$ & $55.07^{c}$ & $29.42^{c}$ & $84.49^{d}$ \\
\hline Weedy check & $6.33^{\mathrm{a}}$ & $7.58^{\mathrm{a}}$ & $6.95^{\mathrm{a}}$ & $185.99^{a}$ & $116.2^{\mathrm{a}}$ & $302.19^{a}$ \\
\hline $\mathrm{SE} \pm$ & 0.179 & 0.248 & 0.362 & 4.199 & 4.234 & 4.133 \\
\hline \multicolumn{7}{|l|}{ Intra spacing (cm) } \\
\hline 20 & 4.80 & 7.73 & $12.53^{\mathrm{a}}$ & $84.94^{\mathrm{b}}$ & 45.90 & $130.84^{d}$ \\
\hline 25 & 4.60 & 7.00 & $11.60^{\mathrm{b}}$ & $89.00 a^{b}$ & 58.08 & $147.08^{c}$ \\
\hline 30 & 4.60 & 7.00 & $11.60^{\mathrm{b}}$ & $106.90^{\mathrm{a}}$ & 62.21 & $169.11^{b}$ \\
\hline 35 & 4.73 & 7.07 & $11.80^{\mathrm{b}}$ & $111.41^{\mathrm{a}}$ & 69.12 & $180.53^{a}$ \\
\hline $\mathrm{SE} \pm$ & 0.159 & 0.222 & 0.235 & 3.898 & 3.930 & 3.755 \\
\hline
\end{tabular}

Means followed by the same letter (s) within a column in each treatment are not significantly different at $5 \%$ using DMRT. * $=$ Significant at $5 \%, \mathbf{N S}=$ not significant. $\mathbf{K g}$ a.i ha $\mathbf{~}^{-1}=$ kilogram active ingredient per hectare, $\mathbf{W A S}=$ weeks after sowing.

Table 3. Effect of weed control methods and intra row spacing on plant height and canopy spread of cowpea at 9WAS in Samaru and Kadawa.

\begin{tabular}{lcccccc}
\hline \multirow{2}{*}{ Parameters } & \multicolumn{3}{c}{ Plant height } & & \multicolumn{3}{c}{ Canopy spread } \\
\cline { 2 - 7 } & Samaru & Kadawa & Mean & Samaru & Kadawa & Mean \\
\hline Weed control (w) & & & & & & \\
Pendimethalin (kg a.i ha-1) & & & & & & \\
1.0 & $29.02^{\mathrm{c}}$ & $26.63^{\mathrm{b}}$ & $27.82^{\mathrm{d}}$ & $56.27^{\mathrm{d}}$ & $73.87 \mathrm{a}^{\mathrm{b}}$ & $65.07^{\mathrm{c}}$ \\
1.5 & $38.11^{\mathrm{b}}$ & $26.69^{\mathrm{b}}$ & $32.40^{\mathrm{c}}$ & $93.08^{\mathrm{c}}$ & $69.23 \mathrm{a}^{\mathrm{b}}$ & $81.16^{\mathrm{b}}$ \\
2.0 & $39.30^{\mathrm{b}}$ & $31.41^{\mathrm{a}}$ & $35.36^{\mathrm{b}}$ & $102.40^{\mathrm{b}}$ & $72.37 \mathrm{a}^{\mathrm{b}}$ & $87.39^{\mathrm{b}}$ \\
Two hoe weeding (3\& 6WAS) & $46.89^{\mathrm{a}}$ & $32.25^{\mathrm{a}}$ & $39.62^{\mathrm{a}}$ & $108.26^{\mathrm{a}}$ & $88.17^{\mathrm{a}}$ & $98.22^{\mathrm{a}}$ \\
Weedy check & $13.85^{\mathrm{d}}$ & $14.26^{\mathrm{c}}$ & $14.05^{\mathrm{e}}$ & $14.13^{\mathrm{e}}$ & $54.52^{\mathrm{b}}$ & $34.32^{\mathrm{d}}$ \\
SE \pm & 0.426 & 0.936 & 0.843 & 1.659 & 6.184 & 2.895
\end{tabular}

\section{Intra spacing $(\mathrm{cm})$}

\begin{tabular}{lllllll}
20 & $31.02^{\mathrm{d}}$ & 27.37 & $29.20^{\mathrm{b}}$ & 72.69 & 69.10 & 70.89 \\
25 & $32.59^{\mathrm{c}}$ & 26.22 & $29.40^{\mathrm{b}}$ & 72.86 & 64.16 & 68.51 \\
30 & $33.79^{\mathrm{b}}$ & 25.75 & $29.77^{\mathrm{ab}}$ & 75.17 & 79.27 & 77.22 \\
35 & $36.33^{\mathrm{a}}$ & 25.72 & $30.03^{\mathrm{a}}$ & 78.59 & 74.02 & 76.30 \\
$\mathrm{SE} \pm$ & 0.381 & 0.837 & 0.783 & 1.484 & 5.532 & 2.688 \\
\hline
\end{tabular}

Means followed by the same letter (s) within a column in each treatment are not significantly different at $5 \%$ using DMRT. * = Significant at 5\%, NS = not significant. $\mathbf{K g}^{\text {a.i ha }}{ }^{-1}=$ kilogram active ingredient per hectare, WAS $=$ weeks after sowing.

than those recorded from application of Pendimethalin at all rates (Table 4). The lowest number of pods per plant was recorded from the weedy check.There was significant effect of intra row spacing on number of pod per plant in both location in which 35 and $30 \mathrm{~cm}$ intra row spacing had higher number of pods per plant than 25 and 
Table 4. Effect of weed control methods and intra row spacing on number of pods per plant and 100 seed weight of cowpea at Samaru and Kadawa.

\begin{tabular}{|c|c|c|c|c|c|c|}
\hline \multirow{2}{*}{ Parameters } & \multicolumn{3}{|c|}{ Number of pods per plant } & \multicolumn{2}{|c|}{100 seed weight $(\mathrm{g})$} & \multirow[b]{2}{*}{ Mean } \\
\hline & Samaru & Kadawa & Mean & Samaru & Kadawa & \\
\hline \multicolumn{7}{|l|}{ Weed control (w) } \\
\hline \multicolumn{7}{|l|}{ Pendimethalin ( $\mathrm{kg}$ a.i ha-1) } \\
\hline 1.0 & $8.00^{c}$ & $8.00^{c}$ & $16.00^{d}$ & $17.25^{c}$ & $16.84^{\mathrm{c}}$ & 34.09 \\
\hline 1.5 & $10.00^{b}$ & $10.00^{\mathrm{b}}$ & $20.00^{c}$ & $18.12^{\mathrm{b}}$ & $18.45^{\mathrm{b}}$ & 36.57 \\
\hline 2.0 & $12.00^{\mathrm{a}}$ & $11.00^{\mathrm{a}}$ & $23.00^{\mathrm{b}}$ & $20.00^{\mathrm{b}}$ & $19.42^{b}$ & 39.42 \\
\hline Two hoe weeding (3\& 6WAS) & $13.00^{\mathrm{a}}$ & $12.00^{\mathrm{a}}$ & $25.00^{\mathrm{a}}$ & $24.53^{\mathrm{a}}$ & $23.84^{a}$ & 48.37 \\
\hline Weedy check & $5.00^{d}$ & $5.00^{d}$ & $10.00^{e}$ & $14.82^{\mathrm{d}}$ & $14.41^{d}$ & 29.23 \\
\hline SE \pm & 0.403 & 0.364 & 0.498 & 0.474 & 0.463 & \\
\hline \multicolumn{7}{|l|}{ Intra spacing (cm) } \\
\hline 20 & $8.00^{\mathrm{b}}$ & $8.00^{\mathrm{b}}$ & $16.00^{\mathrm{b}}$ & $17.98^{\mathrm{b}}$ & $17.64^{b}$ & $35.38^{c}$ \\
\hline 25 & $8.00^{\mathrm{b}}$ & $8.00^{\mathrm{b}}$ & $16.00^{\mathrm{b}}$ & $18.70 \mathrm{a}^{\mathrm{b}}$ & $18.28^{\mathrm{ab}}$ & $36.98^{b}$ \\
\hline 30 & $10.00^{\mathrm{a}}$ & $9.00^{\mathrm{a}}$ & $19.00^{\mathrm{a}}$ & $19.44^{\mathrm{a}}$ & $19.08^{a}$ & $38.52^{a}$ \\
\hline 35 & $10.00^{\mathrm{a}}$ & $9.00^{a}$ & $19.00^{\mathrm{a}}$ & $19.64^{\mathrm{a}}$ & $19.28^{a}$ & $38.92^{a}$ \\
\hline SE \pm & 0.375 & 0.337 & 0.410 & 0.294 & 0.414 & 0.399 \\
\hline
\end{tabular}

Means followed by the same letter (s) within a column in each treatment are not significantly different at $5 \%$ using DMRT. * $=$ Significant at $5 \%$, NS = not significant. $\mathbf{K g}$ a.i ha ${ }^{-1}=$ kilogram active ingredient per hectare, WAS $=$ weeks after sowing.

$20 \mathrm{~cm}$ respectively. Two hoe weeded plot gave the highest 100 seed weight which was significantly higher than other treatments while the lowest was from the weedy check in both locations (Table 4). Generally, in both locations weedy check produced significantly lowest 100 seed weight. The heaviest 100 seed weight was achieved in 35 and $30 \mathrm{~cm}$ spacing in both locations.

\section{Grain yield $\left(\mathrm{kg} \mathrm{ha}^{-1}\right)$}

Cowpea grain yield was significantly affected by weed control methods and intra row spacing in both locations (Table 5). The grain yield was higher in hoe weeded plot followed by application of Pendimethalin at 2.0, 1.5, 1.0 $\mathrm{kg}$ a.i ha-1 and weedy check in that order. The intra row spacing exhibited significant difference with respect to grain yield. Grain yield in $20 \mathrm{~cm}$ plot was significantly higher than those of 25,30 and $35 \mathrm{~cm}$ in that order in both locations.

\section{DISCUSSION}

At both locations, pendimethalin at higher rate of $2.0 \mathrm{~kg}$ a.i ha ${ }^{-1}$ effectively control weed beyond the critical period of cowpea growth. This minimized competition for growth resource between the crops and the weeds particularly during the critical period of weed interference in cowpea leading to greater efficiency in utilizing growth and yield resources by the crop. This also led to vigorous crop growth and development of larger leaf area which intercepted more light for increased dry matter production and yield. This finding agree with that of Dadari (2003) and Silva et al. (2003) who reported that the use of herbicides in cowpea to control weeds appears to be useful and considered to be more effective against weeds. The wider canopy observed in both locations with two hoe weeding and application of pendimethalin at $2.0 \mathrm{~kg}$ a.i ha-1, was because there was effective weed control which suppressed weed growth there-by reducing competition for growth factors between the crops and weeds. The significant increase in cowpea height with application of Pendimethalin and the two hoe weeded plots could attributed to the fact that there was good weed control that ensured availability of growth resource. In both locations weedy check also resulted in shorter plants than all other treatments. The production of shorter plants by the weedy check is because weed competition for growth resources in plants usually retards growth.

The number of pod per plant, 100 seed weight and grain yield were higher in two hoe weeding than other weed control methods. This could be attributed to effective weed control in hoe weeded plots resulting in maximum nutrient utilization which led to production of high assimilation of photosynthates causing increase in grain yield. Similar results were observed on groundnut crop by other researchers (Mubarak 2004; Kumar 2009). They observed that pod yield was greatly increased with good weed control treatments, which encouraged early 
Table 5.Effect of weed control methods and intra row spacing on grain yield of cowpea at Samaru and Kadawa.

\begin{tabular}{|c|c|c|c|}
\hline \multirow{2}{*}{ Parameters } & \multicolumn{3}{|c|}{ Grain yield $\left(\mathrm{kg} \mathrm{ha}^{-1}\right)$} \\
\hline & Samaru & Kadawa & Mean \\
\hline \multicolumn{4}{|l|}{ Weed control (w) } \\
\hline \multicolumn{4}{|l|}{ Pendimethalin (kg a.i ha-1) } \\
\hline 1.0 & $796.86^{d}$ & $718.24^{d}$ & $1515.10^{d}$ \\
\hline 1.5 & $974.02^{c}$ & $891.81^{c}$ & $1865.83^{c}$ \\
\hline 2.0 & $1084.67^{b}$ & $1019.77^{b}$ & $2104.44^{b}$ \\
\hline Two hoe weeding (3\& 6WAS) & $1283.39^{a}$ & $1103.35^{a}$ & $2386.74^{a}$ \\
\hline Weedy check & $248.67^{e}$ & $284.31^{e}$ & $532.98^{e}$ \\
\hline SE \pm & 7.167 & 7.063 & 7.882 \\
\hline \multicolumn{4}{|l|}{ Intra spacing (cm) } \\
\hline 20 & $949.82^{\mathrm{a}}$ & $835.10^{\mathrm{a}}$ & $1784.92^{\mathrm{a}}$ \\
\hline 25 & $884.75^{b}$ & $821.69^{a}$ & $1706.44^{b}$ \\
\hline 30 & $848.57^{b}$ & $802.17^{\mathrm{ab}}$ & $1650.74^{c}$ \\
\hline 35 & $827.01^{c}$ & $755.03^{b}$ & $1582.04^{d}$ \\
\hline $\mathrm{SE} \pm$ & 6.653 & 6.556 & 7.235 \\
\hline
\end{tabular}

Means followed by the same letter (s) within a column in each treatment are not significantly different at $5 \%$ using DMRT. ${ }^{*}=$ Significant at $5 \%$, NS = not significant. $\mathbf{K g}$ a.i ha ${ }^{-1}=$ kilogram active ingredient per hectare, WAS $=$ weeks after sowing.

flowering, developed higher leaf area index, increased number of pods and branches per plant and maximized pod yield. The higher grain yield obtained from application of Pendimethalin at $2.0 \mathrm{~kg}$ a.i ha-1 and two hoe weeding could be associated with the higher number of branches, leaf area index and wider canopy spread. These could have made for greater reception of light leading to increase in photosynthetic process of plants which was required for pod filling and improved grain yield of cowpea in both locations. The superior performance of these treatments as compared to the weedy check could be attributed to their effective in weed suppression that allow better efficiency in the use of available growth and yield resource. The results agree with findings of Adekpe (2004) who observed that crops are known to perform better under good weed management.

The intra row spacing used in this experiment exhibited significant increase in growth and yield parameters of cowpea in both locations. Growth parameters such as plant height, canopy spread and number of branches per plant were significantly affected by intra row spacing. Widely spaced plants $(35 \mathrm{~cm})$ were taller than closely spaced plants $(20 \mathrm{~cm})$. This may be due to sufficient nutrients and light at wider spacing. This may be attributed to vigorous plants with less competition for light, nutrients and space there by resulting in high crop performance. Adigun et al. (2014) reported similar finding. The influence of intra row spacing on yield components such as number of pod per plant, seed weight and grain yield were significantly affected by intra row spacing. The increase in number of pods per plant with increasing plant spacing observed in this study was due to sufficient nutrients and light at wider intra row spacing. This is in line with the finding of El Naim et al. (2010) who reported increase in number of pods per plant with increased intra row spacing. Decreasing plant spacing decreased seed yield per plant in both locations. This was primarily due to the reduced number of pods per plant at closer spacing which led to the production of smaller sized seeds as result of increased competition for available resources such as moisture, sunlight and nutrients. This agrees with the finding of El Naim and Jabereldar (2010) that seed yield per plant substantially decreased with decreased plant spacing. They attributed this reduction to inter plant competition for assimilates and low pod yield. The higher yield obtained at $20 \mathrm{~cm}$ intra row spacing could be attributed to more harvestable plants per unit area which more than compensated for the reduction in yield of individual plants. The significant reduction in weed dry matter production in narrow intra row spacing at 9 WAS in Samaru was due to higher plant populations resulting to early and better canopy formation which enhanced weed suppression. This is in line with the finding of Adigun et al. (2014) who reported significant reduction in weed dry weight in narrow spacing due to better canopy cover of the crop under narrow spacing on cowpea. Reduction in weed bio-mass due to narrow rows has been reported by Tharp and Kells (2001) that crop planted at closer spacing form canopy 
much earlier than those spaced widely apart and result in better weed suppression and low weed dry weight on corn.

\section{Conclusion}

Based on this finding, it can be concluded that hoe weeding at 3 and 6 WAS with intra row spacing of $20 \mathrm{~cm}$ reduced weed infestation and increase grain yield of cowpea in both locations. However, the result of this experiment showed that all rates of pendimethalin applied were not effective in the control of sedges. Thus, a combination of pendimethalin and metolachlor at different rates is recommended for further studies.

\section{CONFLICT OF INTEREST}

The authors declare that they have no conflict of interest.

\section{REFERENCES}

Adekpe, D. I., Shinggu, C. P., Adesanya, A. A., \& Bitrus, C. T. (2004). Effect of pre emergence herbicides on the performance of roselle (Hibiscus sabdariffa) at Samaru Zaria. A paper presented at the 22nd Annual Conference of the Horticultural Society of Nigeria (HORTSON) held at Daula Hotel, Kano 4th-9th July 2004.

Adigun, J. A., Osipitan, A. O., Lagoke, S. T., Raphael, O. A., \& Stephen, O. A. (2014). Growth and yield of cowpea (Vigna unguiculata (L.) Walp) as influenced by row intra row spacing and period of weed interference in South West Nigeria. Journal of Agricultural Science, 6,188-198.

Aggarwal, V. D., \& Ouedraogo, J. T. (1989). Estimation of cowpea yield loss from Striga infestation. Tropical agriculture, 66(1), 91-92.

Akinyemiju, O. A., \& Olaifa, J. A. (1991). Relative Importance of Weeds and Insect Pest Control in Cowpea Production. Nigerian Journal of Weed Science, 4, 43-53.

Akobundu, I. O (1984). Response of cowpea (Vigna unguiculata (L) Walp). Cultivars to pre emergence herbicide IITA P.M.B 5320 Ibadan Nigeria. Nigerian Journal of Plant Protection, 9, 31-35.

Akobundu, I. O. (1987). Weed Science in the Tropics. Principles and Practices. John Wiley and Sons limited, Great Britain, Pp. 159-161.

Bukhtiar, B., Naseem, A., \& Tufail, M. (1992). Weed Control in Lentil under Irrigated Conditions. Pakistan Journal of Weed Science Research, 4, 99-104.

Dadari, S. A. (2003). Evaluation of herbicides in cotton/cowpea mixture in the Northern Guinea Savanna. Journal of Sustainable Agriculture. 5,153-159.

Dugje, I. Y., Omoigui, L. O., Ekeleme, F., Bandyopadhyay, R. P., Lava, K., \& Kumar A. Y. (2009). Farmers Guide to Soya bean Production in Northern Nigeria. IITA, p.7

Duncan, D. B. (1995). Multiple Ranges and multiple F- test. Biometrics, 11, 1-42
El Naim, A, M., \& Jabereldar, A. A. (2010). Effect of Plant density and cultivar on growth and yield of cowpea (Vigna unguiculata (L.)Walp). Australian Journal of Basic and Applied Sciences, 4(8), 3148-3153.

El Naim, A. M., El day, E. M., \& Ahmed, A. A. (2010). Effect of plant density on the performance of some sesame (Sesamum indicumL) cultivars under Rain fed. Research Journal of Agriculture and Biological Sciences, 6(4), 498-504.

Jackai, L., Goudou, C., Asiwe, J., \& Tayo, B. O. (1999). Integrated control of the cowpea (Vigna unguiculata L.) aphid using seed dressing and varietal resistance. Samaru Journal of Agriculture Research, 17, 13-23.

Khan, B. M., Asif, M., Hussain, N., \& lqbal M. (2000). Agro economic impacts of different weed control strategies in wheat, Journal Research Science, 11, 46-49.

Kumar, N. S. (2009). Effect of plant density and weed management practices on production potential of groundnut (Arachishypogea L.). India Journal of Agricultural Research, 43, 1

Mubarak, H. A. (2004). Studies on weed management in irrigated groundnut (Arachishypogea L.) in the Sudan. Ph.D. Thesis. Faculty of Agricultural Science, University of Gezira, Wad Medani (Sudan).

Parasuraman, P. (2000). Weed Management in Rain-fed cowpea (Vignaunguiculata) and green gram (Phaseolusradiatus) under north-western agro-climatic zone of Tamil Nadu. Indian Journal of Agronomy; 45, 732-736.

Patel, M. M., Patel, A. I., Patel, I. C., Takka, S. B. S., Henry, A., Kumar, D., \& Singh, N. B. (2003). Weed control in cowpea under rain fed condition.in proceeding of the national symposium on arid legume, for food nutrition security and promotion of trade. Advances in Arid Legumes Research, Pp. 203-206.

Ross, M. A., \& Lembi, C. A. (1985). Applied Weed Science. Burses publishing company, Minneapolis Minnestota, 35p.

Silva, J. B. F., Pitombeira, J. B., Nunes, R. P., \& Pinto, J. L. N. (2003). Weed Control in Cowpea under no till system. Planta Dawinha, 21, 151-157.

Singh, B. B. (2007). Recent progress in cowpea genetics and breeding. In: International Conference on Indigenous Vegetables and Legumes. Prospectus for Fighting Poverty, Hunger and Malnutrition 752, Pp. 69-76.

Tijjani, E. H. (2001). Influence of intra row spacing and weeding regime on the performance of cowpea [Vignaunguiculata (L.) Walp]. Nigerian Journal of Weed Science, 14, 11-15.

Tomar, R. K., Singh, R. N., Garg, V. K., Gupta, R. N., \& Arora, R. P. (2003). Effect of weed management practices on weed growth and yield in wheat and rice based cropping system under varying levels of tillage. Annals pl Project Science; 11, 123-8.

Tripathi, S. S., \& Singh, G. (2001). Critical period of weed competition in summer cowpea (Vigna unguiculata (L.)) Indian Journal for Weed Science; 33:67-8.

Yadav, R. L. (1998). Factor productivity trends in a rice-wheat cropping system under long-term use of chemical fertilizers. Experimental Agriculture, 34(1), 1-18. 


\section{Appendix}

Appendix Table 1. Physical and chemical properties of soil of the experimental sites at Samaru and Kadawa in 2014/2015 dry season.

\begin{tabular}{lcc}
\hline \multirow{2}{*}{ Composition } & Samaru & Kadawa \\
\cline { 2 - 3 } & $\mathbf{0 - 3 0} \mathbf{~ c m ~}$ & $\mathbf{0 - 3 0 ~} \mathbf{~ m ~}$ \\
\hline Particle Size Analysis (\%) & 36.00 & 58.00 \\
Sand & 6.00 & 36.40 \\
Silt & 58.00 & 5.60 \\
Clay & Silt Loam & Sandy Loam \\
Textural Class & 6.20 & 7.29 \\
$\mathrm{pH} \mathrm{H} \mathrm{H}_{2} \mathrm{O} 1.2 .5$ & 5.66 & 6.85 \\
$\mathrm{pH}$ in 0.01MCaCl 2 & 1.51 & 1.37 \\
Organic Carbon $(\%)$ & 0.51 & 0.42 \\
Total Nitrogen $(\%)$ & 3.07 & 2.20 \\
Available Phosphorus $\left(\mathrm{mg} \mathrm{kg}^{-1}\right)$ & & \\
Exchangeable bases $\left(\mathrm{Cmol} \mathrm{kg}^{-1}\right)$ & 3.50 & 1.90 \\
Ca & 1.60 & 1.45 \\
$\mathrm{Mg}$ & 0.16 & 0.19 \\
$\mathrm{~K}$ & 0.18 & 0.20 \\
$\mathrm{Na}$ & 6.00 & 5.00 \\
Cation Exchange Capacity CEC $\left(\mathrm{Cmolkg}^{-1}\right)$ & & \\
\hline
\end{tabular}

Appendix Table 2a. Meteorological data showing monthly rainfall, air temperature, relative humidity and sunshine hour in 2015 at Samaru.

\begin{tabular}{lcccccc}
\hline \multirow{2}{*}{ Month } & \multirow{2}{*}{ Rainfall $(\mathbf{m m})$} & \multicolumn{3}{c}{ Temperature $\left({ }^{\circ} \mathbf{C}\right)$} & \multirow{2}{*}{ Relative humidity (\%) } & \multirow{2}{*}{ Sunshine hour } \\
\cline { 3 - 5 } & & Max. & Min. & Mean & \\
\hline January & 0.00 & 28.97 & 13.60 & 21.52 & 19.74 & NA \\
February & 0.00 & 31.54 & 15.68 & 23.61 & 12.36 & 6.42 \\
March & 90.90 & 36.19 & 21.13 & 28.66 & 20.45 & 7.37 \\
April & 0.00 & 36.27 & 21.53 & 28.00 & 12.13 & 6.91 \\
May & 90.10 & 37.35 & 21.53 & 30.77 & 52.52 & \\
Total & 180.90 & & & & & \\
Mean & 217.18 & & & & & \\
\hline
\end{tabular}

NA, Not Available. Source: Meteorological Unit of Institute for Agricultural Research (IAR), Ahmadu Bello University, Samaru, Zaria.

Appendix Table 2b.Meteorological data showing monthly rainfall, air temperature, relative humidity and sunshine hour in 2015 at Kadawa.

\begin{tabular}{|c|c|c|c|c|c|c|}
\hline \multirow{2}{*}{ Month } & \multirow{2}{*}{ Rainfall (mm) } & \multicolumn{3}{|c|}{ Temperature $\left({ }^{\circ} \mathrm{C}\right)$} & \multirow{2}{*}{ Relative humidity (\%) } & \multirow{2}{*}{ Sunshine hour } \\
\hline & & Max. & Min. & Mean & & \\
\hline January & NA & 32.52 & 14.77 & 23.65 & 36.29 & 10.50 \\
\hline February & NA & 36.89 & 19.07 & 27.98 & 27.32 & 10.00 \\
\hline March & NA & 37.84 & 22.23 & 30.03 & 28.03 & 7.03 \\
\hline April & 19.40 & 40.67 & 26.10 & 33.38 & 38.80 & 7.86 \\
\hline May & 58.1 & 39.94 & 26.58 & 33.26 & 58.39 & 8.22 \\
\hline Total & 77.50 & & & & & \\
\hline Mean & 15.50 & & & & & \\
\hline
\end{tabular}

NA, Not Available.Source: Meteorological Unit of Institute for Agricultural Research (IAR), Ahmadu Bello University, Samaru, Zaria. 